\title{
Contribution of Lignin and Non-Lignin Dependent Responses in Protein Fraction-Interacted Plant Tissue
}

\author{
Ashraf Gholizadeh ${ }^{1}$ \\ ${ }^{1}$ Research Institute for Fundamental Sciences (RIFS), University of Tabriz, Tabriz, Iran \\ Correspondence: Ashraf Gholizadeh, Research Institute for Fundamental Sciences (RIFS), University of Tabriz, \\ Tabriz, Iran. E-mail: aghz_bioch@yahoo.co.in
}

Received: July 5, 2013 Accepted: September 5, 2013 Online Published: September 23, 2013

doi:10.5539/jps.v3n1p1 URL: http://dx.doi.org/10.5539/jps.v3n1p1

\begin{abstract}
In a basic investigation, considering sunflower (Helianthus annuus) a highly lignified seed plant in contrast to fern (Nephrolepsis exaltata) as pteridophyte, the leaf tissues of Nephrolepsis were allowed to be interacted with the $\left(\mathrm{NH}_{4}\right)_{2} \mathrm{SO}_{4}$ protein fractions of Helianthus leaves. The results showed that the $\left(\mathrm{NH}_{4}\right)_{2} \mathrm{SO}_{4} 60-100 \%$ fraction is able to increase the activities of phenylpropanoid/polyphenolic pathway enzymes including phenylalanine ammonia lyase (PAL), polyphone oxidase (PPO) and peroxidase (POD) in leaf tissues of Nephrolepsis. Comparing changed percentage in lignin contents, antioxidative abilities, total flavonoids and carotenoids content with the changes in the enzymes activities different contributions of lignin and non-lignin dependent responses in the interacted tissues were observed. For the first ever time report, the present findings not only quantify the approximate dividend of the lignin and non-lignin dependent routs in phenylpropanoid pathway but also may state the question: whether a signaling element is present in the protein fraction of sunflower leaves?
\end{abstract}

Keywords: lignin, Nephrolepsis, Peroxidase (POD), Phenylalanine ammonia lyase (PAL), Polyphone oxidase (PPO), sunflower

\section{Introduction}

Lignin is a natural aromatic heteropolymer that is mainly deposited in the xylem tissues of vascular plants through the lignification process during tissue differentiation (Boerjan et al., 2003). It is a branched plant biopolymer generated by radical coupling of hydroxycinnamyl subunits named monolignols, mainly coniferyl, sinapyl and coumaryl alcohols. It provides the mechanical rigidity and strength for vascular plants and makes the cell walls impermeable to water, thus enabling the transport of solutes via tracheids in the xylem tissue of plants (Böhm et al., 2006; Kim et al., 2008).

Besides lignin biosynthesis during the normal growth and developmental processes, lignification has also been known to be occurred in response to different environmental cues such as wounding and pathogen infections (Sirivastava et al., 2007; Kim et al., 2008). Therefore lignin can act as a stress protectant and as a barrier to different pathogens infection offering resistance for stress-challenged plants (Böhm et al., 2006). In all of these lignification-dependent plant defenses and protection processes the shikimic acid pathway and phenylpropanoid metabolism have got more attention due to their initiative involvement in monolignols (lignin precursors) biosynthesis (Boudet, 1998; Lu \& Ralph, 2003).

The biosynthesis of monolignols is generally initiated from the phenylpropanoids where phenylalanine is converted to coumaryl CoA via a series of enzymatic reactions, including the gate enzyme phenylalanine ammonia lyase (PAL; EC 4.3.1.24) (Kervinen et al., 1997; Tao et al., 2011). Besides PAL, Polyphenol oxidase (PPO; EC 1.14.18.1) and peroxidase (POD; 1.11.1.x) enzymes have also been known to be involved in lignin biosynthetic pathway. These two oxido-reductive enzymes are involved in the lignification process through the oxidation of a wide verity of phenolic compounds and contribution to the polymerization process that leads to the lignin molecule (Gomez-Vasquez et al., 2004; Marjamaa et al., 2009).

The activation of PAL, PPO and POD enzymes is a ubiquitous feature of plant responses to the compatible/incompatible interactions between plant and environmental factors. Their activation may either lead to the lignification-dependent protections or may result in lignification-independent protective mechanisms. The 
lignification-dependent protections are usually achieved through the cell wall strengthening, impermeability and repairing by lignin or suberin, while the lignification-independent protective mechanisms are derived from other phenylpropanoid natural products such as phytoalexins, signaling compounds such as salicylic acid, antioxidants mostly including phenolic, flavonoid and carotenoid compounds or active oxygen species as part of the oxidative burst during incompatible interactions (Liang et al., 1989; Hammerschmidt, 1999; Michalak, 2006; Pociecha et al., 2009; Arencibia et al., 2012). On the other hand, the biosynthesis of the specific phenylpropanoid products determines the adaptation or protection routes.

Keeping these differential protection mechanisms in view, the regulation of the biosynthesis and polymerization of lignin monomers or non-lignin products has still been poorly understood. In general, two main regulatory possibilities have been suggested to be concerned with the activation of phenylpropanoid pathway: i) the entry of sugars into the shikimic acid pathway and ii) the entry of phenylalanine into the phenylpropanoid/polyphenolic pathway. However, the regulatory manners or factors which determine the differential contributions of the phenylpropanoid compounds into different protective routs have not yet been unraveled (Whetten \& Sederoff, 1992).

To enhance our basic information with regard to the inducing material / factors of the phenylpropanoid pathway, the leaf tissues of Nephrolepsis plant allowed to be interacted with the sunflower leaf protein fraction. This experiment was aimed on the bases of the significant difference present in lignin contents between the seed plants and pteridophytes. Considering sunflower as a seed plant and Nephrolepsis as pteridophyte, their exogenous interaction was predicted to be responsive. The possible responses were assessed in terms of phenylpropanoid/polyphenolic pathway enzymes activities including PAL, PPO, and POD, lignin contents, antioxidative abilities and total flavonoid and carotenoid contents. The obtained results were discussed in relation to the lignification-dependant protection manner as well as the antioxidative response in plant interactions.

\section{Materials and Methods}

\subsection{Materials}

Sunflower (Helianthus annus L.) seeds and sword fern (Nephrolepsis exaltata) from the families of Aster aceae and Lomariopsidaceae were taken from our laboratory stock. The seeds and all of test plants were germinated in soil and grown under normal laboratory conditions. The growth conditions were included: 12/12 hour day/night photoperiod, laboratory sun light, $28 / 23{ }^{\circ} \mathrm{C}$ day/ night temperatures, and humidity of $65 \%$. Sunflower plant as a highly lignified plant was considered as an inducing material and fern as lowly lignified plant was taken as inducible material.

\subsection{Preparation of Sunflower protein $\left(\mathrm{NH}_{4}\right)_{2} \mathrm{SO}_{4}$ Fractions}

For crude protein extraction, $4 \mathrm{~g}$ of fresh leaf tissues of sunflower was homogenized with $5 \mathrm{ml}$ of $100 \mathrm{mM}$ $\mathrm{K}_{3} \mathrm{PO}_{4}$ buffer solution, $\mathrm{pH} 7.0$, containing $2 \mathrm{mM}$ of EDTA, $1 \%(\mathrm{~m} / \mathrm{v}) \mathrm{PVP}$ (polyvinylpyrrolidone), and $1 \mathrm{mM}$ of PMSF (phenylmethylsulfonyl fluoride). The homogenate was centrifuged at $12000 \times \mathrm{g}$ for $15 \mathrm{~min}$ at $4{ }^{\circ} \mathrm{C}$ and the supernatant was taken as crude protein extract. The leaf extract was subjected to ammonium sulphate fractionation at 0-30, 30-60 and 60-100 percent saturation by slow addition of saturated ammonium sulphate. At each step the precipitated proteins were pelleted by centrifugation at $12000 \times \mathrm{g}$ for $10 \mathrm{~min}$. the pellets were resuspended in potassium phosphate $\left(\mathrm{K}_{2} \mathrm{HPO}_{4} / \mathrm{KH}_{2} \mathrm{PO}_{4}\right)$ buffer, $\mathrm{pH} 7.0$ and dialyzed against the same buffer, over night. In order to observe the morpho-molecular effects of $\left(\mathrm{NH}_{4}\right)_{2} \mathrm{SO}_{4}$ protein fractions of sunflower leaves on the fern plant leaf tissues, the fresh green leaf tissues of fern plant were put in the protein fractions (10 leaves per $20 \mathrm{ml}$ of each fraction) with slow shake. Two following control samples were considered as: (i) leaves put in protein extraction buffer and (ii) leaves put in double distilled water. The leaves were then observed for the possible morpho-molecular changes for 7 days at one-day time intervals. Treated leaves were observed for the morphological changes by naked eye. The molecular analysis was carried out in terms of propanoid pathway enzymes assay, and determination of the lignin amount, antioxidative ability and the leaf color representing pigments.

\subsection{Determination of the Enzyme Activities}

\subsubsection{Preparation of Enzyme Extract}

About $200 \mathrm{mg}$ of the treated fresh leaves was cut and homogenized in $1 \mathrm{ml}$ of $0.1 \mathrm{M}$ phosphate buffer, $\mathrm{pH} 7.0$, containing $0.5 \mu \mathrm{l}$ of 2-mercaptoethanol (sigma, 99.0\%) and a pinch of PVP. The homogenate was centrifuged at $12,000 \times \mathrm{g}$ for $10 \mathrm{~min}$ and the supernatant was used for the enzymes activity assay. 


\subsubsection{PAL Activity Assay}

Phenylalanine ammonia lyase activity was assayed according to Gowdin et al. (1996). The reaction mixture contained $100 \mathrm{mM}$ of Tris- $\mathrm{HCl}$ buffer, $\mathrm{pH} 8.5,1 \mathrm{mM}$ of 2-mercaptoethanol, $15 \mathrm{mM}$ of L-phenyalanine, and 100 $\mu \mathrm{l}$ enzyme extract. The reaction mixture was incubated at $30{ }^{\circ} \mathrm{C}$ for $15 \mathrm{~min}$, and reaction was ended by the addition of $6 \mathrm{M} \mathrm{HCl}$ and then the absorbance was measured at $290 \mathrm{~nm}$. The percentage of increase in the absorbance was considered as the percentage of increase in the enzyme activity.

\subsubsection{PPO Activity Assay}

Polyphenol oxidase activity was determined according to Siriphanich and Kader (1985). The $1 \mathrm{ml}$ reaction mixture contained $20 \mu \mathrm{l}$ enzyme extract (as same for PAL activity) and $10 \mathrm{mM}$ of phosphate buffer, $\mathrm{pH}$ 7.0. After 2 min aeration, the reaction was followed by the addition of catechol as the substrate at a final concentration of $20 \mathrm{mM}$ and subjected to the measuring the absorbance at $420 \mathrm{~nm}$. The percentage of increase in the absorbance was considered as the percentage of increase in the enzyme activity.

\subsubsection{POD Activity Assay}

Peroxidase activity was determined according to Lin and Kao (2001). The reaction mixture contained $50 \mu 1$ of 20 $\mathrm{Mm}$ guaiacol, $2.8 \mathrm{ml}$ of $10 \mathrm{mM}$ phosphate buffer (pH 7.0), and $0.1 \mathrm{ml}$ enzyme extract. The reaction was initiated by addition of $20 \mu \mathrm{l}$ of $40 \mathrm{mM} \mathrm{H}_{2} \mathrm{O}_{2}$. One unit of the enzyme was considered as the amount of the enzyme that was responsible for the increase in OD value of $0.1 \mathrm{in} 1 \mathrm{~min}$ at $470 \mathrm{~nm}$. Percentage of increase in the absorbance was considered as the percentage of increase in the enzyme activity.

\subsection{Determination of Lignin Contents}

Lignin concentration was determined according to Ferrarese (2002). About $2 \mathrm{~g}$ of the fresh sample leaves was

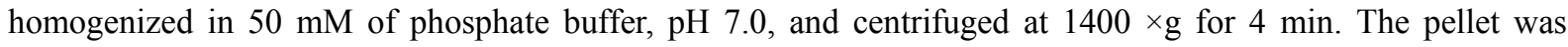
centrifuged at $1400 \times \mathrm{g}$ for $4 \mathrm{~min}$ and washed by successive stirring and centrifugation as follows: twice with phosphate buffer, three times with $1 \%(\mathrm{v} / \mathrm{v})$ Triton X-100 containing buffer, twice with $1 \mathrm{M} \mathrm{NaCl}$ containing buffer, twice with distilled water and twice with acetone. The pellet was left for drying in an oven at $60{ }^{\circ} \mathrm{C}$ for 24 h. To $0.1 \mathrm{~g}$ of the dried material, a reaction mixture containing $1.2 \mathrm{ml}$ thioglycolic acid, $6 \mathrm{ml}$ of $2 \mathrm{M} \mathrm{HCl}$ were added and then heated at $95{ }^{\circ} \mathrm{C}$ for $4 \mathrm{~h}$. After cooling at room temperature, the sample was centrifuged at $1400 \mathrm{~g}$ for $5 \mathrm{~min}$ and the supernatant was decanted. The pellet was washed three times with distilled water, and the lignin-thioglycolic acid was extracted by shaking at $30^{\circ} \mathrm{C}$ in $0.5 \mathrm{M} \mathrm{NaOH}$ for $18 \mathrm{~h}$. After centrifugation at 1400 $\times \mathrm{g}$ for $5 \mathrm{~min}$, the supernatant was stored. The pellet was washed again with $0.5 \mathrm{M} \mathrm{NaOH}$ and mixed with the supernatant obtained earlier. The combined alkali extract was acidified with $1.8 \mathrm{ml}$ of $\mathrm{HCl}$. The lignothioglycolic acid formed after $4 \mathrm{~h}$ at $0{ }^{\circ} \mathrm{C}$ was recovered by centrifugation at $1400 \times \mathrm{g}$ for $5 \mathrm{~min}$ and then washed twice with distilled water. The pellet was dried at $60^{\circ} \mathrm{C}$, dissolved in $0.5 \mathrm{M} \mathrm{NaOH}$, and proceeded for the absorbance assay at $280 \mathrm{~nm}$ (Böhm et al., 2006). The percentage of increase/decrease in the absorbance was considered as the percentage of increase/deacrease in the lignin amount.

\subsection{Total Antioxidant Power Assay}

The total antioxidative ability of the samples was determined using ferric reducing antioxidant power (FRAP) assay (Benzie \& Strain, 1996). For each assay, a reaction mixture was prepared by the addition of $1 \mathrm{ml}$ of plant fresh leaf extract in $0.1 \mathrm{M}$ phosphate buffer (pH 7.0), $3 \mathrm{ml}$ of FRAP reagent (including $10 \mathrm{mM} \mathrm{TPTZ:} \mathrm{tripyridyl}$ triazine, $20 \mathrm{mM} \mathrm{FeCl}_{3} \cdot 6 \mathrm{H}_{2} \mathrm{O}$ and $300 \mathrm{mM}$ sodium acetate buffer (pH 3.6) in the ratio of 1: 1: 10) and it was incubated at $37^{\circ} \mathrm{C}$ for $4 \mathrm{~min}$. The assessment was carried out spectrophotometerically at $593 \mathrm{~nm}$. The changes in the absorbance of the test samples based on controls were presented as the percentage of changes in anitoxidation ability.

\subsection{Total Flavonoid Assessment}

Total flavonoid contents of the samples were colorimetrically measured by using aluminum chloride assay (Zhishen et al., 1999). To $1 \mathrm{ml}$ of the fresh leaf extract, $4 \mathrm{ml}$ double distilled water, $0.3 \mathrm{ml} \mathrm{NaNO} \mathrm{N}_{2}(5 \%), 0.3 \mathrm{ml}$ $\mathrm{AlCl}_{3}$ after $5 \mathrm{~min}, 2 \mathrm{ml} \mathrm{NaOH}$ after $6 \mathrm{~min}$ were added and diluted to $10 \mathrm{ml}$. The absorbance of the samples was measured at $510 \mathrm{~nm}$. The changes in the absorbance of the test samples based on controls were presented as the percentage of changes in flavonoid content.

\subsection{Total Carotenoid Assay}

Total carotenoid contents of the samples were measured by a spectrophotometric method using acetone and petroleum ether as extracting solvents and measuring the absorbance at $450 \mathrm{~nm}$ (Ranganna, 1997). Briefly, the successive additions of acetone were made and transferred into a funnel coupled to a Buchner flask and filtered 
under vacuum. The extract obtained was then transferred to a separatory funnel containing $40 \mathrm{~mL}$ of petroleum ether. After removing acetone and adding anhydrous sodium sulfate, the volume was made up by petroleum ether, and the samples were read at $450 \mathrm{~nm}$. The percentage of increase/decrease in the absorbance was considered as the percentage of increase/decrease in the carotenoid content.

\subsection{Statistics}

Data points on the graphs represent the means values of two replications \pm SD in each treatment or experiment. Variance analysis was carried out by ANOVA at $p \leq 0.05$.

\section{Results and Discussion}

\subsection{Changes in Enzyme Activities}

The environmental plasticity is the striking feature of plants development process in which plants exhibit a number of adaptative and protective responses to environmental cues. One of the most important protectants belongs to phenylpropanoid natural products that are originated from phenylalanine. These compounds mostly include the cell wall structural polymer lignin which also acts as a wound protectant and barrier to pathogen infection, some flavonoid pigments and UV protectants, phytoalexins as well as the antioxidative phenolic/polyphenolic compounds (Solecka, 1997; Michalak, 2006; Pociecha et al., 2009; Arencibia et al., 2012). In this protective pathway, the roles of PAL, PPO and POD enzymes have been well understood. PAL is known to catalyze the first committed step of the core pathway of general phenylpropanoid metabolism, while the branch pathways are catalyzed by several enzymes such as PPO and POD that lead to the synthesis of compounds having diverse biological functions in plant system (Almagro et al., 2009).

To enhance our basic information about the inducing materials of this protective metabolic pathway, the leaf tissues of Nephrolepsis plant was allowed to be interacted with the $0-30 \%, 30-60 \%$ and $60-100 \%\left(\mathrm{NH}_{4}\right)_{2} \mathrm{SO}_{4}$ protein fractions of sunflower leaves. Considering the significant difference in the lignin amounts, the interactions between these two plants were predicted to be responsive. The results showed that no morphological changes are occurred in the interacted leaves during 7 days experimental period (detected by naked eye; photograph not presented). While, the tested enzyme activities are changed, daily. The results revealed that the considerable changes in the enzymes activities are only observed in $60-100 \%\left(\mathrm{NH}_{4}\right)_{2} \mathrm{SO}_{4}$ fraction-interacted tissues. In these tissues, PAL activity was found to be increased (about 53\%) during the first 4 days, but it started to decrease (to the level of about 34\%) thereafter (Figure 1). The activity of PAL was unchanged in the buffer and water interacted control leaves. The increased activity of PAL has been previously reported in response to various biotic and abiotic stresses in plant system (Liang et al., 1989; Dixon \& Paiva 1995; Chen et al., 2009; Gholizadeh \& Baghbankohnehrouz, 2010; Ziaeil et al., 2012). The elevations in PAL activity has been shown in both compatible and incompatible plant interactions with environmental cues. However, the increase in this enzyme activity and accumulation of its mRNA have been found to be more rapid and higher in the cases of incompatible interactions (Liang et al., 1989; Panina et al., 2005; Choudhary, 2011). The previous reports have shown that the activity of PAL in response to phytophthora capsici attack can be elevated up to about $80 \%$ in pepper during nine days (Hu-zhe et al., 2005). Analysis of the data obtained by our experiment suggests that the response of the protein fraction-interacted tissues can be comparable with the incompatible pathogen-plant interaction responses in terms of PAL activity.

Similar to PAL, PPO activity was also found to be increased by $49 \%$ in the protein fraction-interacted leaves for the first 4 days and then started to slowly decrease to $39 \%$ (Figure 1). The control samples did not exhibit variations during experimental period. Like PAL, the increase in the enzymatic activity of PPO has been previously reported in response to various biotic and abiotic interactive environments in plants (Ray et al., 1998; Lee et al., 2007). However, our experiment revealed that the protein fraction of a plant also enable to induce a comparable interactive and responsive environment for other plant tissues.

The results showed that POD activity is sharply increased by $61 \%$ in the protein fraction-interacted leaves for the first 4 days but it is declined very slowly thereafter (Figure 1). The higher elevations in POD activity have been previously reported in stress-challenged plants. Its percentage of increase has been shown to be even reached up to more than $100 \%$ in the cases of incompatible plant-pathogen interactions (Hu-zhe et al., 2005). Usually among PAL, PPO and POD the activity of POD is numerously reported to be more elevated than two other enzymes. 


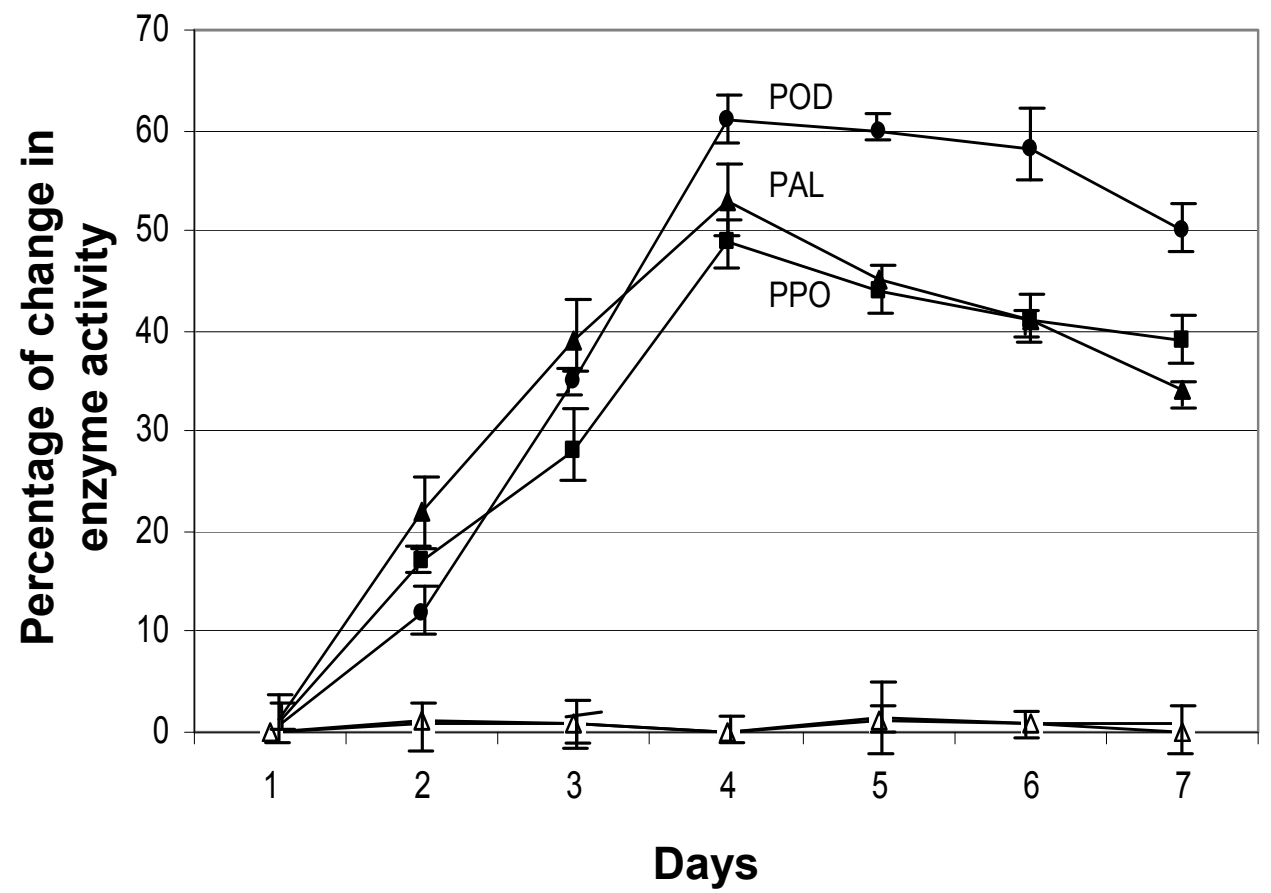

Figure 1. Percentage of changes in enzyme activities

The changes in the PAL, PPO and POD activities were assessed by measuring the changes in the absorbance of the samples at 290, 420 and $470 \mathrm{~nm}$ respectively and presented as percentage of changes in compare to controls. Data presented as the means of the two replicates.

In overall, the present results showed that the changes in the activities of PAL, PPO and POD undergo a similar increase / decrease patterns during experimental period. Their percentages of increase are reached to the maximum levels at the day 4 and their percentages of decrease occur thereafter. Considering the increase / decrease patterns in the enzyme activities and the absence of morphological changes in the interacted tissues, it can be suggested that the enzymatic modulations are necessarily occurred to adapt/ protect the interacted tissues against the stimulating factor/factors that might be present in the protein fraction. Usually, morphological changes are appeared after enzymatic protection responses. Plants induce several physio-molecular symptoms to protect themselves against various biotic and abiotic stimuli, while they alleviate morphological changes as the result of their failure in molecular manners (Ray et al., 1998; Hu-zhe et al., 2005). Our experiment results also indicate that enzymatic modulations are prior to the morphological changes in a protein fraction-interacted plant tissue. In our opinion, the increase pattern of enzyme activities is induced for the protection of plant tissues at early stage, while the decrease module is occurred at adapted stage after protection.

\subsection{Changes in the Lignin Amounts}

In plants, the activation of PAL, PPO and POD enzymes may either lead to the lignification-dependent protections or may result in lignification-independent protective mechanisms. The lignification-dependent protections are usually achieved through the strengthening of cell wall and the impermeability (Liang et al., 1989; Boudet, 1998; Sirivastava et al., 2007; Kim et al., 2008).

Considering sunflower as a seed plant having much higher content of lignin than the Nephrolepsis plant as a pteridophyte, their exogenous interactions was predicted to be responsive with regard to the lignification process. In order to find out the possible involvement of the tested enzymes in the lignification process, the lignin contents were measured in the protein fractions-interacted leaves and compared to that of control samples. The results revealed that the amount of the lignin is considerably increased in $60-80 \%\left(\mathrm{NH}_{4}\right)_{2} \mathrm{SO}_{4}$ protein fraction-interacted leaf tissues as compared to the buffer and water interacted controls (Figure 2). In these tissues, the percentage of increase was found to be reached to the level of $36 \%$ for the first 4 days and remained constant thereafter. The two other fractions as well as the buffer/water interacted control samples were remained unchanged during the experimental period. Comparison of the lignin data with the tested enzymes activities indicated that the pattern of increase in lignin content is similar to the increase modulation of PAL, PPO and 
POD activities during 4 days. However, the next constant pattern of the lignin content slightly differs from the decrease pattern of the enzyme activities between the days 4 and 7 . This result may suggest that lignin is not degraded after synthesis in the plant tissues. Plants that are exposed to different stresses change lignin content and composition. In many cases, such as mineral deficiency, drought, ultraviolet-B radiation, low temperatures as well as biotic stresses, such as infection by fungi, bacteria and viruses, it has been suggested that the increase in lignin amount is a common defense responses of plants to the stress (reviewed by Moura et al., 2010).

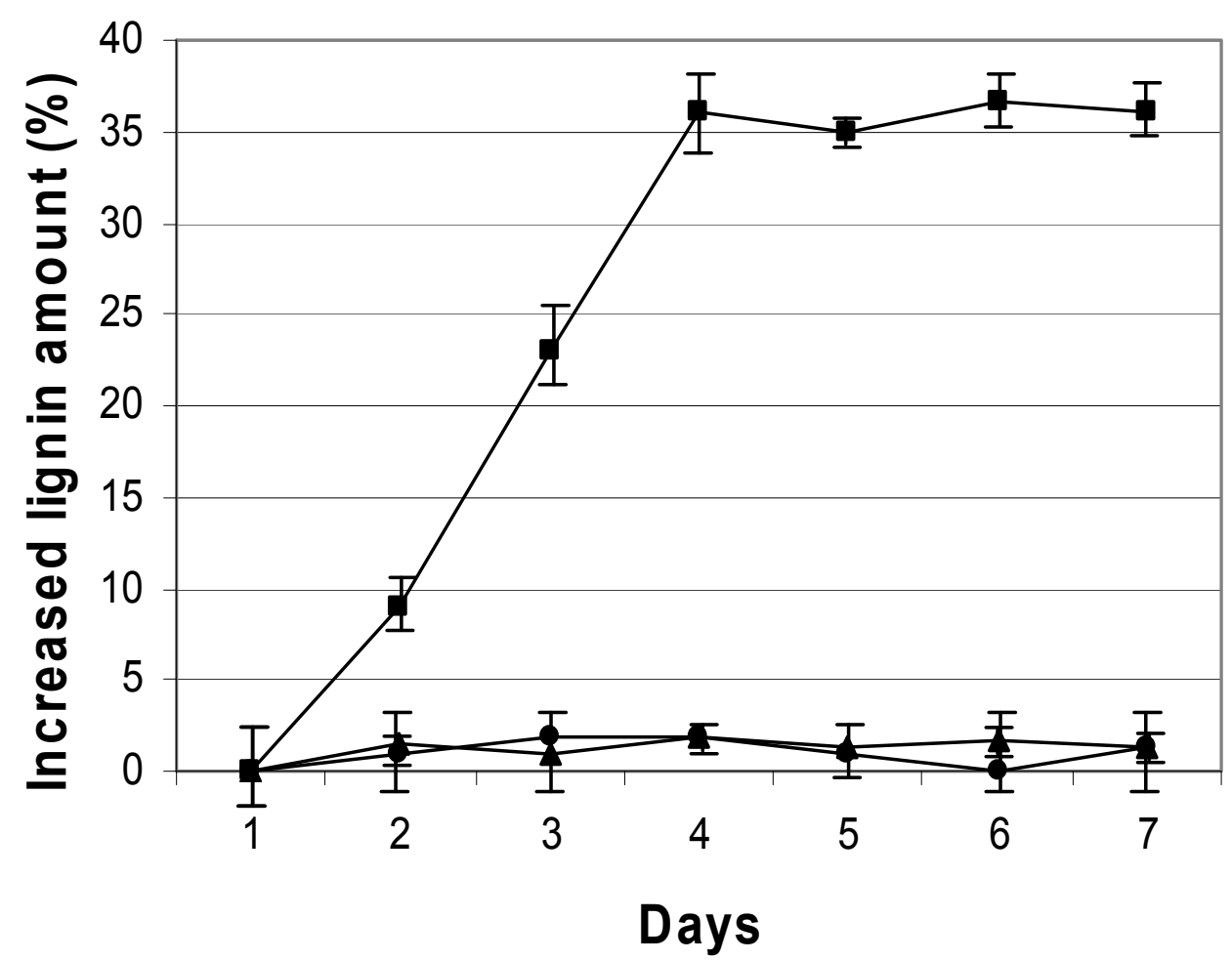

Figure 2. Percentage of changes in lignin amount

The changes in the lignin amount in the protein-free samples were measured spectrophotometerically at $280 \mathrm{~nm}$ and presented as percentage of changes in compare to controls. Closed squires: protein fraction-treated test samples; Closed triangles: buffer-treated controls; Closed circles: non-treated controls. Values are the means of the two replicates.

Comparison of the percentages of increase in lignin amounts with the activities of test enzymes predicts that about $35 \%$ of the enzymes activities may contribute to the lignin biosynthesis in the protein fraction-interacted tissues for the first 4 days.

\subsection{Changes in the Antioxidative Status}

Besides lignin biosynthesis, PAL, PPO and POD are involved in the biosynthesis of non-lignin products such as phytoalexins, signaling compounds such as salicylic acid, antioxidants mostly including phenolic compounds or active oxygen species as part of the oxidative burst during incompatible interactions (Liang et al., 1989; Passardi et al., 2005; Donnini et al., 2011). To find out the possible involvement of the tested enzymes in the antioxidation status of the protein fraction-interacted leaves, the total antioxidative abilities of the test and control samples were assessed and compared using FRAP method. The obtained results showed that the antioxidative status of the $60-80 \%\left(\mathrm{NH}_{4}\right)_{2} \mathrm{SO}_{4}$ protein fraction-interacted leaves is reached to the maximum level of about $27 \%$ at day 4 and then started to decline to the level of $21 \%$ during the next 3 days (Figure 3 ). The related percentages of the controls samples were remained unchanged during the experimental period. This result indicated that the pattern of the elevation in the antioxidative ability of the test tissues follows the increase/decrease modulation of the test enzymes activities. Comparison of the data related to the antioxidative abilities with the enzymes activities predicts that about $25 \%$ of PAL, PPO and POD activities may contribute to the biosynthesis of the non-lignin 
compounds possibly including antioxidative phenolic/polyphenolics that are generally synthesized by phenylpropanoid pathway. PAL, PPO and POD are not only responsible enzymes in lignification apparatus in plants, but also they are known as the key components of the antioxidative system of various stress-challenged plants (Stepien \& Klobus, 2005; Gholizadeh \& BaghbanKohnehrouz, 2010). Our experiment data may restate this question that how much does antioxidative sterategy help to the protection process of protein fraction-interacted plant tissue.

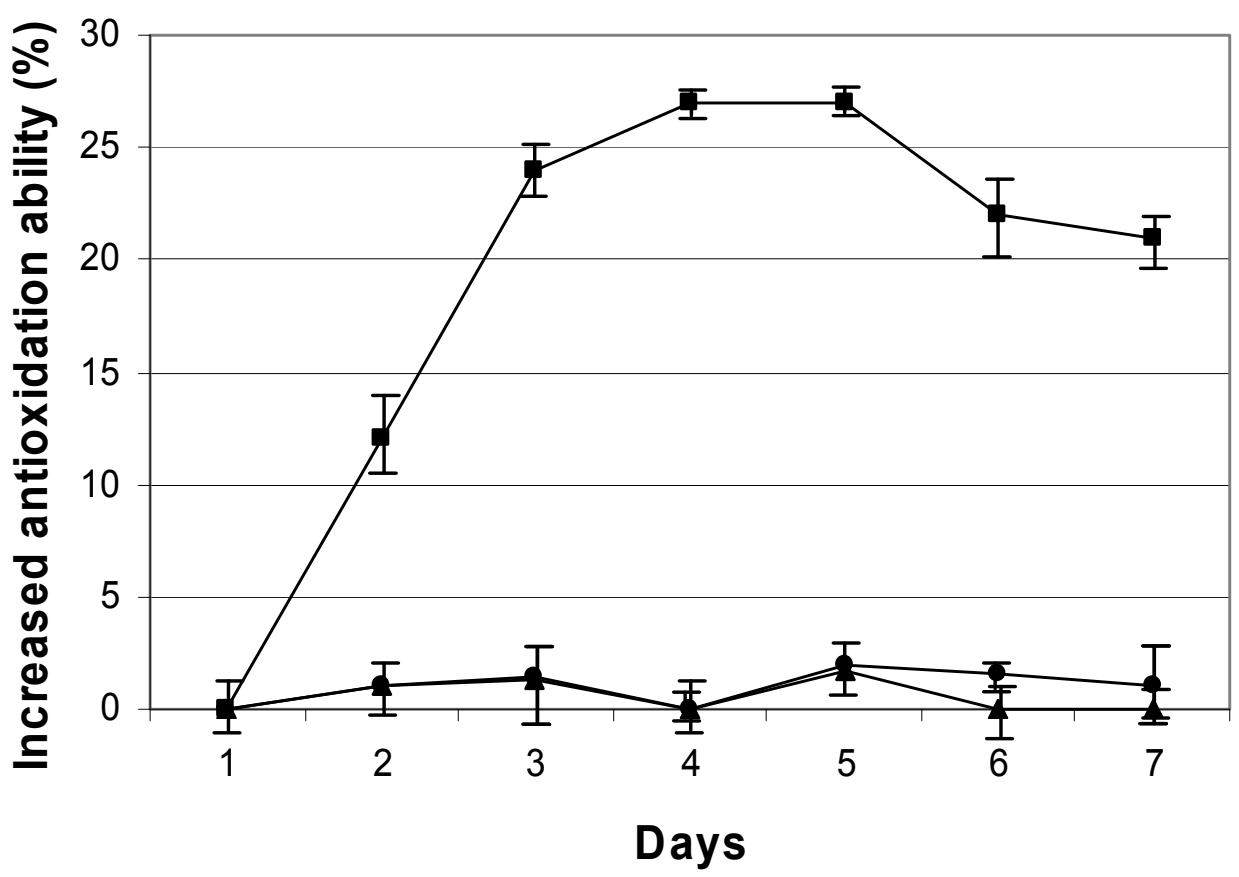

Figure 3. Percentage of changes in total antioxidation status

The total antioxidative abilities of the samples were assessed by using the ferric reducing antioxidant power (FRAP) test and presented as the percentage of changes in compare to controls. Closed squires: protein fraction-treated test samples; Closed triangles: buffer-treated controls; Closed circles: non-treated controls. Data are the means of the two replicates.

\subsection{Changes in the Flavonoid and Carotenoid Contents}

Flavonoids and carotenoids are mostly responsible compounds in pigmentation process in flowers or leaves of plants. They respectively belong to phenolic and isopropanoid metabolic pathways, known as ubiquitous secondary metabolites in plant system (Harborne \& Turner, 1984; Ramamoorthy \& bono, 2007). Due to their redox properties, they are not only contributed to the color of the plant tissues but also they have been numerously reported to be involved in the antioxidation capacity of the cells under various environmental cues such as salinity, UV-B radiation and nitrogen deficiency (reviewed by Fini et al., 2011). They play an important role in absorbing and neutralizing free radicals, quenching oxygen or decomposing peroxides allowing them to act as reducing agents or hydrogen donors (Beckmen \& Ames, 2000). Analysis of the flavonoid and carotenoid contents in the test leaves showed their percentages of increase are about 4.4 and 6.1 during the experimental period (Figure 4). Despite the test enzymes activities and lignin contents, the flavonoid and carotenoid contents were found to be continuously increased during the experimental period. This may be consistent to the protective roles of flavonoids and carotenoids in various stress-challenged plants (Strzałka et al., 2003; Fini et al., 2011).

Comparison of the patterns of changes in the flavonoid and carotenoid contents with the data related to the change modulations in the antioxidative ability of the interacted tissues, it seems that flavonoids and carotenoids exert their protective roles independent of their antioxidative abilities. 


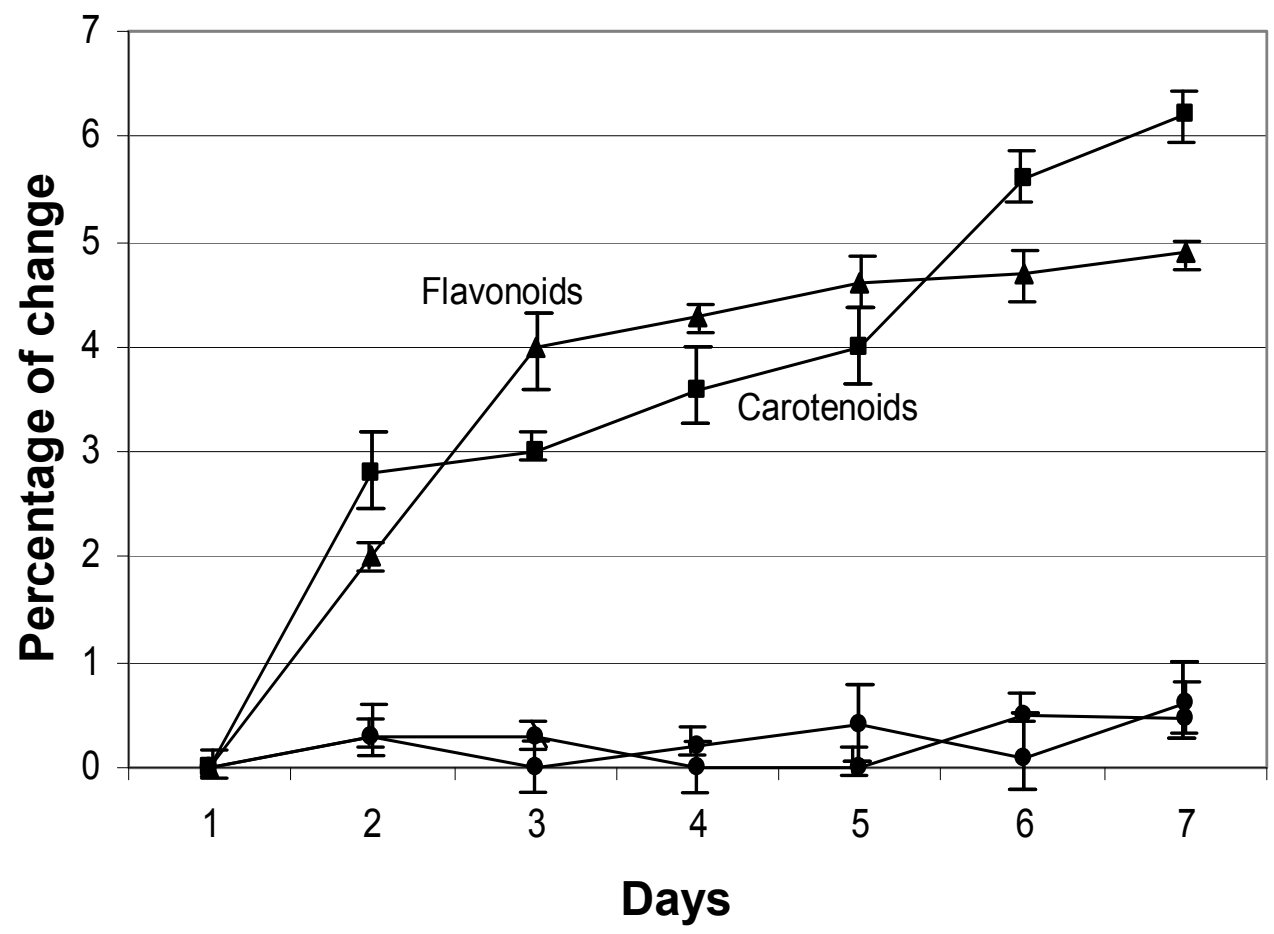

Figure 4. Percentage of changes in total flavonoid and carotenoid contents

The total flavonoid contents of the samples were determined using aluminum chloride method by measuring the absorbance of the samples at $510 \mathrm{~nm}$. The total carotenoid contents of the samples were assessed using acetone and petroleum ether as extracting solvents and measuring the absorbance of the samples at $450 \mathrm{~nm}$.

The present investigation results together revealed that the contact of $60-100 \%\left(\mathrm{NH}_{4}\right)_{2} \mathrm{SO}_{4}$ protein fraction of the sunflower leaves with the Nephrolepsis leaf tissues leads to a responsive interaction. Analysis of the phenylpropanoid/polyphenolic pathway-related enzymes activities indicated that their considerable changes follow the similar modulation (increasing or decreasing) during the overall interaction period of 7 days. Assessments of the lignin contents, the total antioxidative abilities, flavonoids and carotenoids contents of the protein fraction-interacted tissues revealed that their overall increase or decrease patterns are almost parallel with the model of changes in enzymes activities. Despite the similarities in their patterns of change, analysis of the data showed that their percentages of change are considerably differs from those of the enzymes activities. Comparison of the maximum values of the lignin (about 35\%), antioxidants (about 25\%), flavonoids and carotenoids (about 10\%) contents with the changes in enzymes activities (about $60 \%$ ) interestingly revealed that the protective response of the Nephrolepsis tissues to the protein fraction of sunflower undergoes two different manners including: i) lignin-dependent mechanism possibly by strengthening in the interacted tissues and ii) lignin-independent response most likely through the antioxidative strategy and pigmentation through flavonoids and carotenoids which share about $10 \%$. On the other hand, based on our occlusions, the $60 \%$ of tested enzymes activity can be divided to about $35 \%$ lignin biosynthesis and $35 \%$ non-lignin routes including antioxidation (25\%) and pigmentation (10\%). A schematic representation of this assay and proposing is shown (Figure 5). Since the approximate summation of the percentages of changes in lignin contents and the antioxidation abilities was estimated to be equal to the percentages of changes in the activities of PAL, PPO and POD enzymes, therefore no other phenylpropanoid related mechanism was predicted in this responsive interaction. 


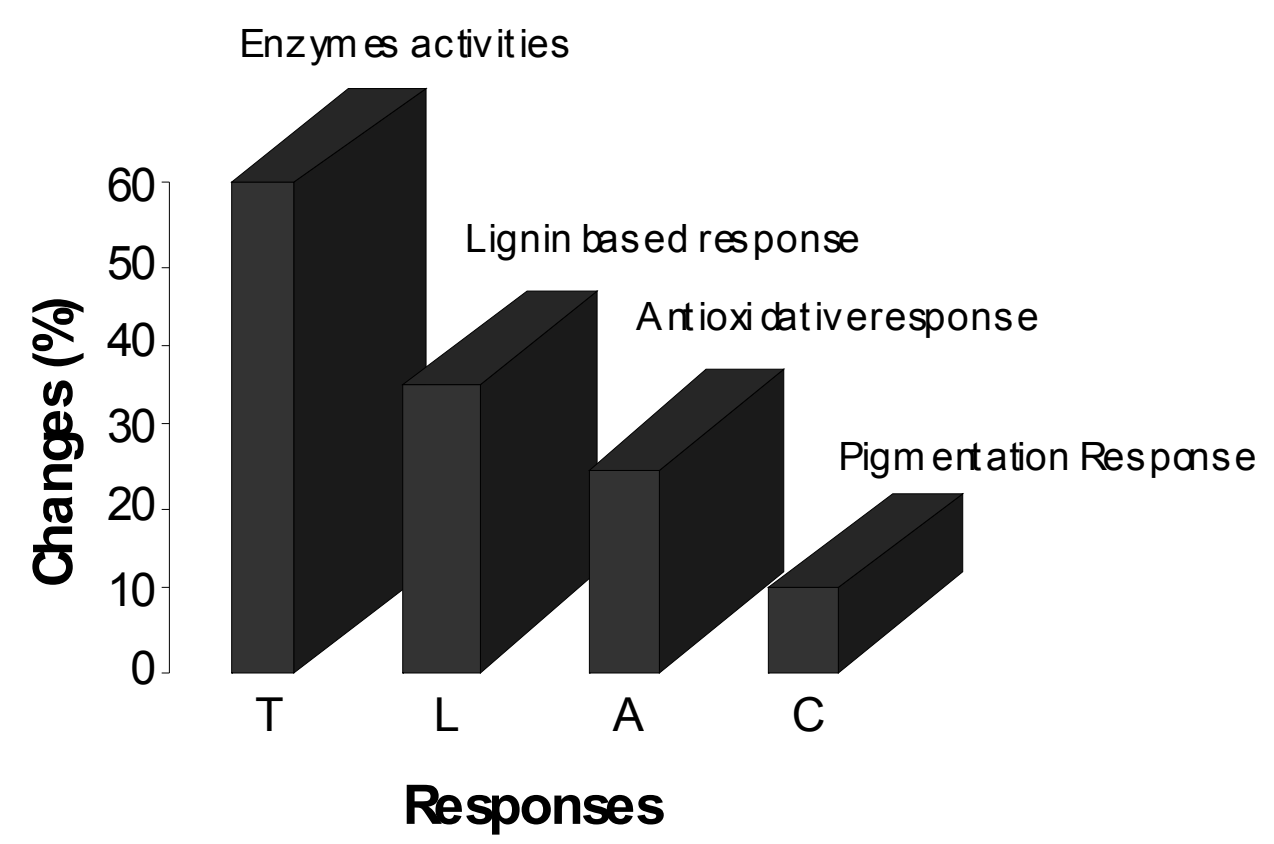

Figure 5. Representation of the responses ration

Dividend of the total enzymes activities (T) into the lignification-dependent response (L), the antioxidative response (A) and the color (pigmentation) response (C) in protection process were predicted to be about $35 \%$, $25 \%$, and $10 \%$ respectively.

PAL, PPO and POD had been variously reported to regulate oxidative/antioxidative activities in numerous cell compartments and thus involve in many plant processes, such as growth and biotic/ abiotic stress responses (Passardi et al., 2005). Additionally, these enzymes had been reported to be involved in lignin biosynthesis by the production of monolignols and assembling the lignin units through oxidative polymerization (Liang et al., 1989; Polle et al. 1994). Several works had well documented that the increase in lignification process is induced under some growth and environmental cues to adapt plants to the new conditions (Kim et al., 2008; Lee et al., 2007). But, all of these reports have been separately signified the lignification or oxidation/antioxidation protective roles in plants under adverse conditions. Recently, Donnini group have studied both these protective roles together and found that oxidative stress responses and root lignification are simultaneously induced by Fe-deficiency conditions in pear and quince genotypes (Donnini et al., 2011).

Later on as the first ever time report, our simultaneous comparative studies on the activities of phenylpropanoid pathway enzymes and their products led to the approximate quantification of the lignin and non-lignin dependent contributions of phenylpropanoid pathway in an interacted plant tissue. In addition, our findings may also state the question: whether an inducing/ signaling factor is present in the $60-100 \%\left(\mathrm{NH}_{4}\right)_{2} \mathrm{SO}_{4}$ protein fraction of sunflower leaf tisues? As ammonium sulphate fractionation of protein extract eliminates the implications of purine, pyrimidine and carbohydrate compounds, therefore the most likely role and involvement of a proteineous factor is predicted.

As our information about the regulation processes of the lignin biosynthetic pathway as well as non-lignin routes is still poor, therefore the regulatory mechanisms by which the differential contributions of the phenylpropanoid compounds into different protective routs are determined, need to be investigated in the future studies.

\section{Acknowledgments}

The author of this paper is thankful to the Research Institute for the Fundamental Sciences (RIFS) and University of Tabriz for the financial support of this work.

\section{References}

Almagro, L., Gomez Ros, L.V., Belchi-Navarro, S., Bru, R., Ros Barcel, A., \& Pedre no, M. A. (2009). Class III Peroxidases in Plant Defense Reactions. J Exp Bot, 60, 377-390. http://dx.doi.org/10.1093/jxb/ern277 
Arencibia, A. D., Bernal, A., Zayas, C., Carmona, E., Cordero, C., González, G., ... Santana, I. (2012). Hydrogen peroxide induced phenylpropanoids pathway eliciting a defensive response in plants micropropagated in Temporary Immersion Bioreactors (TIBs). Plant Sci, 195, 71-79. http://dx.doi.org/10.1016/j.plantsci.2012.06.016

Beckman, K. B., \& Ames, B. N. (Eds.). (2000). Oxidants and Agingin. Amsterdam: Elsevier.

Benzie, F. F., \& Strain, J. J. (1996). The Ferric Reducing Ability of Plasma as Leisure of Antioxidant Power, The FRAP assay. Anal Biochem, 239, 70-76. http://dx.doi.org/10.1006/abio.1996.0292

Boerjan, W., Ralph, J., \& Baucher, M. (2003). Lignin Biosynthesis. Annual. Rev Plant Biol, 54, 519-546. $\mathrm{http} / / / \mathrm{dx}$.doi.org/10.1146/annurev.arplant.54.031902.134938

Böhm, P. A. F., Zanardo, F. M. L., Ferrarese, M. L. L., \& Ferrarese, F. (2006). Peroxidase Activity and Lignification in Soybeen Root Growth-Inhibition by Juglone. Biol Plant, 50, 315-317. http://dx.doi.org/10.1007/s10535-006-0029-x

Boudet, A. M. (1998). A new view of lignifications. Trends Plant Sci, 3, 67-71. http://dx.doi.org/10.1016/S1360-1385(97)01176-X

Chen, J. Y., He, L. H., \& Jiang, Y. M. (2009). Expression of PAL and HSPs in Fresh-Cut Banana Fruit. Environ. Exp Bot, 66, 31-37. http://dx.doi.org/10.1016/j.envexpbot.2008.12.019

Choudhary, D. K. (2011). Plant growth-promotion (PGP) activities and molecular characterization of rhizobacterial strains isolated from soybean (Glycine max L. Merril) plants against charcoal rot pathogen, Macrophomina phaseolina. Biotechnol Lett, 33, 2287-2295. http://dx.doi.org/10.1007/s10529-011-0699-0

Dixon, R. A., \& Paiva, N. L. (1995). Stress-Induced Phenylpropanoid Metabolism. Plant Cell, 7, 1085-1097. http://dx.doi.org/10.1105/tpc.7.7.1085

Donnini, S., Dell'Orto, M., \& Zocchi, G. (2011). Oxidative Stress Responses and Root Lignification Induced by $\mathrm{Fe}$ Deficiency Conditions in Pear and Quince Genotypes. Tree Physiol, 31, 102-113. http://dx.doi.org/10.1093/treephys/tpq105

Ferrarese, M. L. L., Zottis, A., \& Ferrarese, F. O. (2002). Protein Free Lignin Quantification in Soybean (Glycine max) Roots. Biology (Sect Biol), 57, 541-543.

Fini, A., Brunetti, C., Di Ferdinando, M., Ferrini, F., \& Tattini, M. (2011). Stress-induced flavonoid biosynthesis and the antioxidant machinery of plants. Plant Signal Behav, 6, 709-711. http://dx.doi.org/10.4161/psb.6.5.15069

Gholizadeh, A., \& BaghbanKohnehrouz, B. (2010). Activation of Phenylalanine Ammonia Lyase as a Key Component of the Antioxidative System of Salt-Challenged Maize Leaves. Braz J Plant Physiol, 22, 217-223. http://dx.doi.org/10.1590/S1677-04202010000400001

Godwin, B., D’Cunha Satyanarayan, V., \& Madhusudanan Nair, P. (1996). Purification of Phenylalanine Ammonia Lyase from Rhodotorula glutinis. Phytochemistry, 42, 17-20. http://dx.doi.org/10.1016/0031-9422(95)00914-0

Gomez-Vasquez, R, Day, R., Buschmann, H., Randles, S., Beeching, J. R., \& Cooper, R. M. (2004). Phenylpropanoids, Phenylalanine Ammonia Lyase and Peroxidases in Elicitor-challenged Cassava (Manihot esculenta) Suspension Cells and Leaves. Ann Bot, 94, 87-97. http://dx.doi.org/10.1093/aob/mch107

Hammerschmidt, R. (1999). Pytoalexines: what have we learned after 60 years. Ann Rev Phytopathol, 37, 285-306. http://dx.doi.org/10.1146/annurev.phyto.37.1.285

Harborne, J. B., \& Turner, B. L. (Eds.). (1984). Plant Chemosystematics. London: Academic Press.

Hu-zhe, Z., Chun-lan, C., Yu-ting, Z., Dan, W., Yu, J., \& Kil Yong, K. (2005). Active Changes of Lignification-Related Enzymes in Pepper Response to Glomus intraradices and/or Phytophthora capsici. J Zhejiang Univ Sci, 6B, 778-786. http://dx.doi.org/10.1631/jzus.2005.B0778

Kervinen, T., Peltonen, S., Utriainen, M., Kangasjarvi, J., Teeri, T. H., \& Karjalainen, R. (1997). Cloning and Characterization of cDNA Clones Encoding Phenylalanine Ammonia-Lyase in Barley. Plant Sci, 123, 143-150. http://dx.doi.org/10.1016/S0168-9452(96)04570-0

Kim, Y. H., Kim, C. Y., Song, W. K., Park, D. S., Kwon, S. Y., Lee, H. S., ... Kwak, S. S. (2008). Over Expression of Sweetpotato swpa4 Peroxidase Results in Increased Hydrogen Peroxide Production and Enhance Stress Tolerance in Tobacco. Planta, 227, 867-881. http://dx.doi.org/10.1007/s00425-007-0663-3 
Lee, B. R., Kim, K.Y., Jung, W. J., Avice, J. C., Ourry, A., \& Kim, T. H. (2007). Peroxidases and Lignification in Relation to the Intensity of Water-Deficit Stress in White Clover (Trifolium repens L.). $J$ Exp Bot, 58, 1271-1279. http://dx.doi.org/10.1093/jxb/erl280

Liang, X., Dron, M., Crameri, C. L., Dixon, R. A., \& Lamb, C. J. (1989). Differential Regulation of Phenylalanine Ammonia-lyase Genes during Plant Development and by Environmental Cues. J Biol Chem, 264, 14486-14492.

Lin, C. C., \& Kao, C. H. (2001). Cell Wall Peroxidase Activity, Hydrogen Peroxide Level and NaCl-Inhibited Root Growth of Rice Seedlings. Plant and Soil, 230, 135-143. http://dx.doi.org/10.1023/A:1004876712476

Lu, F. C., Ralph, J., Morreel, K., Messens, E., \& Boerjan, W. (2004). Preparation and relevance of a cross-coupling product between sinapyl alcohol and sinapyl hydroxybenzoate. Org Biomol Chem, 2, 2888-2890. http://dx.doi.org/10.1039/b411428k

Marjamaa, K., Kukkola, E. M., \& Fagerstedt, K. V. (2009). The Role of Xylem Class III Peroxidases in Lignification. $J \operatorname{Exp}$ Bot, 60, 367-376. http://dx.doi.org/10.1093/jxb/ern278

Michalak, A. (2006). Phenolic compounds and their antioxidant activity in plants growing under heavy metal stress. Polish J Environ Stud, 15, 523-530.

Moura, J. C. M. S., Bonine, C. A. V., Viana, J. O. F., Dornelas, M. C., \& Mazzafera, P. (2010). Abiotic and Biotic Stresses and Changes in the Lignin Content and Composition in Plants. J Integ Plant Biol, 52, 360-376. http://dx.doi.org/10.1111/j.1744-7909.2010.00892.x

Panina, Y. S., Gerasimova, N. G., Chalenko, G. I., Vasyukova, N. I., \& Ozeretskovskaya, O. L. (2005). Salicylic Acid and Phenylalanine Ammonia-Lyase in Potato Plants Infected with the Causal Agent of Late Blight. Russ J Plant Physiol, 52, 511-515. http://dx.doi.org/10.1007/s11183-005-0075-9

Passardi, F., Cosio, C., Penel, C., \& Dunand, C. (2005). Peroxidases have More Functions than a Swiss Army Knife. Plant Cell Rep, 24, 255-265. http://dx.doi.org/10.1007/s00299-005-0972-6

Pociecha, E., Płażek, A., Janowiak, F., Waligórski, P., \& Zwierzykowski, Z. (2009). Changes in abscisic acid, salicylic acid and phenylpropanoid concentrations during cold acclimation of androgenic forms of Festulolium (Festuca pratensis $\times$ Lolium multiflorum) in relation to resistance to pink snow mould (Microdochium nivale). Plant Breed, 128, 397-403. http://dx.doi.org/10.1111/j.1439-0523.2009.01664.x

Polle, A., Otter, T., \& Seifert, F. (1994). Apoplastic Peroxidases and Lignification in Needles of Norway Spruce (Picea abies L.). Plant Physiol, 106, 53-60.

Ramamoorthy, P. K., \& Bono, A. (2007). Antioxidant activity, total phenolic and flavonoid content of morinda citrifolia fruit extracts from various extraction processes. J Eng Sci Technol, 2, 70-80.

Ranganna, S. (Eds.). (1997). Manual of Analysis of Fruit and Vegetable Products. Tata Mc Graw Hill, New Delhi.

Ray, H., Douches, D. S., \& Hammerschmidt, R. (1998). Transformation of Potato with Cucumber Peroxidase Expression and Disease Response. Physiol Mol Plant Physiol, 53, 93-103. http://dx.doi.org/10.1006/pmpp.1998.0164

Siriphanich, J., \& Kader, A. A. (1985). Effects of $\mathrm{CO}_{2}$ on Total Phenolics, Phenylalanine Ammonia Lyase, and Polyphenol Oxidase in Lettuce Tissue. J Am Soc Horti Sci, 110, 249-253.

Solecka, D. (1997). Role of Phenylpropanoid Compounds in Plant Responses to Different Stress Factors. Acta Physiol Plant, 19, 257-268. http://dx.doi.org/10.1007/s11738-997-0001-1

Stepien, P., \& Klobus, G. (2005). Antioxidant defense in the leaves of $\mathrm{C}_{3}$ and $\mathrm{C}_{4}$ plants under salinity stress. Physiol Plant, 125, 31-40. http://dx.doi.org/10.1111/j.1399-3054.2005.00534.x

Srivastava, V., Schinkel, H., Witzell, J., Hertzberg, M., Torp, M., Srivastava, M. K., ... Wingsle, G. (2007). Downregulation of High Isoelectric Point Extra Cellular Superoxide Dismutase Mediates Alterations in the metabolism of Reactive Oxygen Species and Developmental Disturbances in Hybrid Aspen. Plant J, 49, 135-148. http://dx.doi.org/10.1111/j.1365-313X.2006.02943.x

Strzałka, K., Kostecka-Gugała, A., \& Latowski, D. (2003). Carotenoids and Environmental Stress in Plants: Significance of Carotenoid-Mediated Modulation of Membrane Physical Properties. Russ J Plant Physiol, 50, 168-173. Tao, J., Cao, C., Zhao, D., Zhou, C., \& Liang, G. (2011). Molecular Analysis and Expression of Phenylalanine Ammonia-Lyase from Poinsettia (Euphorbia pulcherrima willd.). Afric J Biotechnol, 10, 
126-135. http://dx.doi.org/10.1023/A:1022960828050

Whetten, R. W., \& Sederoff, R. R. (1992). Phenylalanine Ammonia-Lyase from Loblolly Pine: Purification of the Enzyme and Isolation of Complementary DNA Clones. Plant Physiol, 98, 380-386. http://dx.doi.org/10.1104/pp.98.1.380

Zhishen, J., Mengcheng, T., \& Jianming, W. (1999). The Determination of Flavonoid Contents in Mulberry and Their Scavenging Effects on Superoxide Radicals. Food Chem, 64, 555-559. http://dx.doi.org/10.1016/S0308-8146(98)00102-2

Ziaei, M., Sharifi, M., Behmanesh, M., \& Razavi, K. (2012). Gene Expression and Activity of Phenyl Alanine Amonialyase and Essential Oil Composition of Ocimum basilicum L. at Different Growth Stages. Iran J Biotechnol, 10, 34-39.

\section{Copyrights}

Copyright for this article is retained by the author(s), with first publication rights granted to the journal.

This is an open-access article distributed under the terms and conditions of the Creative Commons Attribution license (http://creativecommons.org/licenses/by/3.0/). 